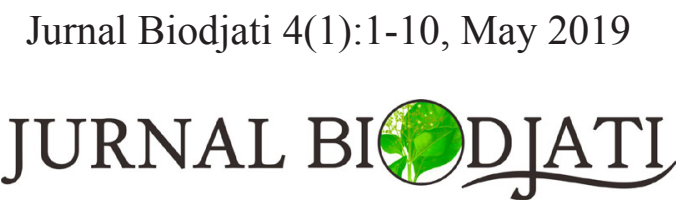

e-ISSN : 2541-4208

p-ISSN : 2548-1606

http://journal.uinsgd.ac.id/index.php/biodjati

\title{
MOLECULAR CHARACTERIZATION REVEALS GENETIC DIFFERENCES BETWEEN WILD AND CAPTIVE POPULATIONS OF MANDIANGIN GIANT GOURAMI (Osphronemus goramy)
}

\author{
Agus Nuryanto*1, Maria Bramasti Susilo², Adi Amurwanto $^{3}$
}

Received : January 03, 2019

Accepted : February 14, 2019

DOI: 10.15575/biodjati.v4i1.3942

${ }^{1,2,3}$ Faculty of Biology, Universitas Jenderal Soedirman. Jl. Dr. Soeparno No 63 Purwokerto 53122, telp. 0281638794, fax. 0281-631700

e-mail:

*1anuryanto2003@yahoo.com

${ }^{2}$ maria.brmstrs@gmail.com

3adibiologi@gmail.com

*Corresponding author

\begin{abstract}
Captive population of Mandiangin giant gourami (Osphronemus goramy Lac.) is a new strain developed from wild populations in Riam Kanan Dam. No much is known about the genetic constituent of this strain compared to the parental population. This research was done to obtain information whether genetic alteration has occurred in captive population compared to their wild parental population. Wild population was caught from Riam Kanan Dam, while captive population was collected from Balai Perikanan Budidaya Air Tawar (BPBAT) "Freshwater Aquaculture Centre" Mandiangin, South Kalimantan. The captive population of Batanghari strain from BPBAT Sungai Gelam, Jambi was also analyzed. Molecular assessment was done using CO1 PCR-RFLP which was developed by digesting the amplicon of the CO1 gene from all populations using two restriction enzymes, namely HindIII and TaqI and resulted CO1-HindIII and CO1-TaqI RFLP markers. All tested populations showed uniform patterns of those CO1-RFLP markers but with different fragment sizes among populations. This means all resulted RFLP markers were monomorphic in each populations but polymorphic among giant gourami populations. In other words, no genetic diversity within population but substantial genetic differences was observed between wild and captive Mandiangin populations. This proved that genetic alteration has occurred in Mandiangin captive populations compared to the wild parental giant gourami population. In conclusion, captive and wild populations of Mandiangin giant gourami were genetically different. This result is vital as scientific base for future development of inland fisheries, especially for breeding strategy of Mandiangin giant gourami.
\end{abstract}

Keywords: genetic difference, gourami, Mandiangin, polymorphism.

\section{Citation}

Nuryanto, A., Susilo, M. B. \& Amurwanto, A. (2019). Molecular Characterization Reveals Genetic Differences Between Wild and Captive Populations of Mandiangin Giant Gourami (Osphronemus goramy). Jurnal Biodjati, 4(1), 1-10.

\section{INTRODUCTION}

Modern taxonomy conception state that species is a group of populations. As the consequences, species are separated into many local populations. Therefore, taxonomically it can be subjected to population structure analysis. Local populations can also be resulted from captive breeding which was conducted to fulfil human likelihood. Captive breeding is 


\section{JURNAL BIDDJATI}

http://journal.uinsgd.ac.id/index.php/biodjati

long history on giant gourami (Osphronemus goramy Lac.) freshwater aquaculture in Indonesia. These efforts result in various strains of giant gourami. According to (Setijaningsih et al., 2007), five strains of giant gourami have been cultivated in Java that is Soang, Jepang, Paris, Bastar and Porcelain Strains. Moreover, Nuryanto \& Pulungsari (2017) also reported that Tambago, Orange and Batanghari Strains have been widely cultivated in Sumatera, while Mandiangin Strain newly developed in Mandiangin, South Kalimantan.

Initially, all giant gourami strains were developed from wild parental populations. In the case of captive population of Mandiangin Strain, it has been cultivated for long period of times through multi-steps of breeding selection from their wild parental population inhabit Riam Kanan Dam, South Kalimantan by Balai Perikanan Budidaya Air Tawar (BPBAT) "Freshwater Aquaculture Centre" Mandiangin, South Kalimantan (Tajung et al., 2011). Previous study from Yoon \& Park (2002) had proved that genetic difference can be observed between wild and cultivated fish.

Breeding selection is an artificial directional selection with the objective to obtain individuals with certain quantitative character(s) that give advantage for human being. In the case of the captive Mandiangin giant gourami, breeding selections were performed in order to obtain individuals with higher growth performance compared to their wild parental and to previously released strain, such as Bastar and Soang from West Java. These breeding selections might lead some alleles become missing in captive population compared to the wild populations while allele with desired quantitative character become more abundance in the population. As a result, captive population might have different genetic constituent compared to their wild parental population.
Information about the genetic constituent of captive population of Mandiangin strain, however, is still limited because this strain is new to science, including their mitochondrial genome such as cytochrome c oxidase 1 gene. Therefore, it was not known whether genetic different is occurred between hatchery and wild populations of Mandiangin giant gourami. Systematic study, such as study on population structure allows people to differentiate two populations. In the case of Mandiangin giant gourami, population structure can be done using DNA-based molecular characters (Nuryanto et al., 2018).

Molecular characterization has been done to several strains of giant gourami, such as Soang Strain (Sari et al., 2014; Azizah et al., 2015; Septiawan et al., 2017) and Batanghari, Tambago and Orange Strains (Nuryanto et al., 2018). Similar study has also been done on Mandiangin Strain using partial sequences of cytochrome $b$ gene and proved that Mandiangin Strain was genetically different from Soang, Tambago, Orange and Batanghari Strains (Nuryanto \& Pulungsari, 2017). Nevertheless, Nuryanto \& Pulungsari (2017) was unable to differentiate between wild and captive populations of Mandiangin Strain because they used rather less polymorphic genetic marker which was cytochrome $b$ gene. Therefore, polymorphic genetic marker is needed to differentiate between cultivated and wild populations of Mandiangin Strain such as cytochrome c oxidase 1 (COX1/CO1) gene.

In this study we used $\mathrm{CO} 1$ gene as highly variable and common genetic marker applied in population structure study. Accumulated study proved that $\mathrm{CO} 1$ gene is highly variable among individuals in broad animal phyla (Kochzius \& Nuryanto, 2008; Ward et al., 2008a; Ward et al., 2008b; Nuryanto \& Kochzius, 2009; Ward et al., 2009). The 


\section{JURNAL BIDDJATI}

http://journal.uinsgd.ac.id/index.php/biodjati

PCR-RFLP markers of cytochrome c oxidase 1 gene were also showed high variability in Polymesoda erosa (Nuryanto \& Sastranegara, 2013). Highly significant genetic differences on the CO1 gene were also observed among Soang, Tambago, Orange and Batanghari Strains with the Fst values range from 0.394 between Tambago and Soang up to 0.655 between Soang and Batanghari (Nuryanto et al., 2018). Therefore, it is expected that high variability of cytochrome c oxidase 1 gene is reliable to be utilized as PCR-RFLP marker to differentiate between wild and captive populations of Mandiangin giant gourami.

This research aimed to study the molecular character of wild and captive populations of Mandiangin giant gourami to reveal whether genetic changes has occurred in captive population. The information available in this study is vital as scientific base for future development of inland fisheries, especially for breeding strategy of Mandiangin giant gourami.

\section{MATERIALS AND METHODS}

A total of 15 caudal fin samples of each Mandiangin population and 10 caudal fin samples of Batanghari strain captive population were subjected to PCR-RFLP analysis. Mandiangin captive population was collected from BPBAT Mandiangin, while wild population was collected from Riam Kanan Dam, South Kalimantan. Batanghari captive population was collected from BPBAT Sungai Gelam Jambi. The DNA analysis was performed at Animal Taxonomy Laboratory, Universitas Jenderal Soedirman since January up to May 2018.

Template DNA was isolated from all samples using Chelex ${ }^{\circledR}$ method (Walsh et al., 2013). The CO1 marker was amplified in vitro using PCR technique. The PCR reactions was adjusted to final volume of $50 \mu \mathrm{l}$ consisting of
$37.4 \mu \mathrm{l}$ of $\mathrm{ddH}_{2} \mathrm{O}, 1 \mathrm{X}$ buffer PCR, $0.02 \mathrm{mM}$ $\mathrm{MgCl}, 0.4 \mathrm{mM}$ NzyTech dNTPs, 0.4 picomol of each primer, $0.02 \mathrm{U}$ NzyTech DNA Taq Polymerase and $3 \mu 1$ template DNA. The marker was amplified using FishF2 5'-TCGACTAATCATAAAGATATCGGCAC-3' as forward primer and FishR2 5'-ACTTCAGGGTGACCGAAGAATCAGAA-3' as reverse primer (Ward et al, 2005). Amplification of the marker was conducted with thermal cycles as follows: initial denaturation was done at $95^{\circ} \mathrm{C}$ for 5 minutes and continued with 35 cycles. Denaturation steps were done at $95^{\circ} \mathrm{C}$ for five minutes, annealing for 5 minutes at $53^{\circ} \mathrm{C}$ and chain elongation was performed at $72^{\circ} \mathrm{C}$ for 1.5 minutes. Final elongation was conducted at $72^{\circ} \mathrm{C}$ for 5 minutes.

The CO1 PCR-RFLP markers were developed through digesting CO1 PCR products using HindIII and TaqI enzymes. Digestion process was conducted following the protocol provided by the company (Thermo Fisher Scientific USA). PCR-products were digested in total volumes of $32 \mu 1$ mixtures; consisted of $18 \mu \mathrm{l}$ of nuclease free water, $10 \mu \mathrm{l}$ of PCR products, $2 \mu 1$ of $10 \mathrm{X}$ digestion buffer, and 2 $\mu l$ of restriction enzymes. The mixtures were incubated for 4 hours in thermomixer with the following optimum temperatures: $37^{\circ} \mathrm{C}$ for HindIII and $65^{\circ} \mathrm{C}$ for TaqI enzymes, respectively. The digested CO1 PCR products were migrated in $1 \%$ agarose and stained with ethidium-bromide. The DNA bands appeared on agarose gel referred as PCR-RFLP profile.

The size of CO1 PCR products and CO1 PCR-RFLP bands were determined using linear regression analysis at 5\% significance levels after their migration distances were compared to the migration distances of $100 \mathrm{bp}$ DNA ladder. The example of regression calculation is presented in Table 1 . The pattern of resulted CO1 PCR-RFLP profiles were analysed descriptively to reveal wheth- 


\section{JURNAL BIDDJATI}

http://journal.uinsgd.ac.id/index.php/biodjati

er polymorphic marker are observed among populations. Once polymorphic markers are observed, further genetic differentiation analysis was performed on wild and captive Mandiangin populations. Qualitative data of RFLP bands were transformed into quantitative binary data $0: 1(0=$ absent; $1=$ present $)$. Genetic diversity within populations was estimated as haplotype diversity $\mathrm{h}$ and locus diversity $\pi$ (Nei \& Jin, 1989). Genetic differences between wild and captive Mandiangin populations were analysed statistically using analysis of molecular variance (AMOVA). The calculations were performed in Arlequin software version 3.5 (Excoffier \& Lischer, 2010)

\section{RESULTS AND DISCUSSION}

\section{Genetic Polymorphism}

Linear regression analysis proved that fragments of $657 \mathrm{bp}$ and $656 \mathrm{bp}$ length of the cytochrome c oxidase 1 were successfully amplified from wild and captive populations of Mandiangin strain, respectively. The size of $655 \mathrm{bp}$ length fragment was obtained from Batanghari strain (Table 1, Figure 1). The obtained sizes were similar to which was reported by Nuryanto et al. (2018) and Ward et al. (2005). Fragments size of 657 bp, 656 bp, and $655 \mathrm{bp}$ were little bit longer than, but still in close proximity with, the fragments size of the other freshwater fish or marine fish. Some families of freshwater fish such as Ariidae, Batrachoididae, Haemulidae, Scatophagidae and Triacanthidae have \pm 650 bp CO1 gene (Anna, 2015). Several marine fish species inhabited the South China Sea have \pm 652 bp length fragments (Zhang \& Hanner, 2012). However, comparison to Anna (2015) and Zhang \& Hanner (2012) was not fully congruent since those two previous studies utilized rather different primers pairs. Anna (2015) used mammal primer cocktail from Ivano- va et al. (2007) and other primer mixtures, meanwhile Zhang \& Hanner (2012) used C FishF1t1/C_FishR1t1 primer cocktails from Ivanova et al. (2007). Therefore, we were convinced that our fragments were the correct target of amplifications. Our confidence was supported by Nuryanto et al. (2018) that 657 bp, $656 \mathrm{bp}$, and $655 \mathrm{bp}$ length fragments of the CO1 gene were the correct target of amplifications after being sequenced and translated into amino acid sequences. The resulted amino acid sequences were referred as functional cytochrome c oxidase 1 enzyme.

Digestion of the amplified CO1 fragments of all populations using selected enzymes (HindIII and TaqI) showed different results. Digestion used HindIII enzyme showed that the PCR products could be digested into two RFLP fragments, either from wild or captive populations of Mandiangin or Batanghari Strains. At a glance, all populations seemed to have similar pattern of RFLP makers. Detailed and careful examination, however, proved that the RFLP markers have different fragments size. The wild Mandiangin populations have RFLP fragments with $395 \mathrm{bp}$ and 262 bp length, while captive population have $408 \mathrm{bp}$ and $248 \mathrm{bp}$ fragments length, whereas the RFLP fragments of Batanghari strain have a length of $404 \mathrm{bp}$ and $251 \mathrm{bp}$ length, respectively (Figure 2). Similar pattern of two RFLP fragment of $\mathrm{CO} 1$ gene digested by HindIII enzyme was reported in Soang Strain although result in different fragments size, e.g. $385 \mathrm{bp}$ and $270 \mathrm{bp}$ length (Azizah et al., 2015). Both our result and the result from (Azizah et al., 2015) indicated that the CO1 gene of giant gourami has one restriction site for HindIII restriction enzyme and the resulted RFLP markers varies among strains. These mean each strain has their own uniqueness.

The CO1-PCR products of wild and captive populations of Mandiangin and Bat- 


\section{JURNAL BIDDJATI}

http://journal.uinsgd.ac.id/index.php/biodjati

anghari population could be digested by $T a q \mathrm{I}$ enzyme into three RFLP fragments (Figure 3). This result proved that all populations have two recognition sites for TaqI enzyme in their $\mathrm{CO} 1$ gene. Our result was similar to the $\mathrm{CO} 1$ gene of Coregonus sardinella (Olsen et al., 2007) which have also two restriction sites for TaqI enzyme.

Careful observation proved that wild population of Mandiangin Strain has RFLP fragments of $319 \mathrm{bp}, 200 \mathrm{bp}$ and $136 \mathrm{bp}$ length. The Mandiangin captive population has of $319 \mathrm{bp}, 211 \mathrm{bp}$ and $126 \mathrm{bp}$ fragments length, while captive population of Batanghari Strain has RFLP fragments with the size of $311 \mathrm{bp}, 211 \mathrm{bp}$, and $133 \mathrm{bp}$ length, respectively. Those results proved that the three populations have different RFLP markers. Different size of RFLP markers were also reposted in Coregonus sardinella (Olsen et al., 2007) when they CO1 genes were digested by TaqI enzyme. The similarities between our study and the studies from (Olsen et al., 2007) proved that CO1-RFLP markers are widely varies among strains and species.

Skimming observation seems that all populations have similar pattern of RFLP markers. Nevertheless, deeper observation on the agarose gels showed that similarity and differences fragments size were found among populations. These differences mean that each population has their own unique allele and also indicates that the used CO1 PCRRFLP markers were polymorphic among populations. However, similar pattern and size of the CO1 PCR-RFLP markers were observed within population. This indicates that the CO1-RFLP markers were monomorphic within population. Similar complex pattern of mtDNA PCR-RFLP polymorphism was observed in Salmo truta (Apostolidis et al., 2008). The CO1-RFLP markers polymorphism among the studied giant gourami pop- ulations but monomorphic within population indicate that the used markers were only reliable for population differentiation but not for genetic diversity analysis within population.

\section{Genetic Differentiation Between Wild and- Captive Populations}

High genetic homogenity was observed within population. A detail genetic diversity values are summarized in Table 2. No genetic diversity within population on CO1-RFLP markers were also observed in Soang giant gourami (Azizah et al., 2015). Our result also showed similar to the result in Salmo truta which was also showed low genetic diversity within population when it was examined using RFLP markers (Apostolidis et al., 2008). No and low genetic diversity values as observed in our study and studies from Azizah et al. (2015) and Apostolidis et al. (2008) indicate that CO1-RFLP markers were not reliable for genetic diversity analysis within population. This could be due to that RFLP marker can only be utilized for observing variation in the restriction sites, whereas the variation that present outside the restriction sites could not be recognized. It is because restriction enzymes were designed only to recognize specific site along DNA sequences (Gholizadeh \& Kohnehrouz, 2008; Santoso et al., 2008). Whenever, there is no variation on restriction sites, genetic homogeneity will be observed. In contrast, whenever restriction sites are variable, high genetic diversity will be observed.

Different result was observed on among population genetic structure analysis. The $\Phi$-st value of 1.000 and variance component value of 0.500 indicate that significant genetic differences were observed among populations ( $p$-value: 0.000). Complete genetic difference values are presented in Table 3. Our finding was similar to the result from Apostolidis et al. (2008) who also reported significant genet- 


\section{Jurnal Biodjati 4(1):1-10, May 2019 \\ JURNAL BIDDJATI}

http://journal.uinsgd.ac.id/index.php/biodjati

ic different among Salmo truta populations. Similar result was also reported by Nuryanto \& Pulungsari (2017); Nuryanto et al. (2018) who also observed significant genetic different among giant gourami strains from Sumatera, Java, and Kalimantan. This means that the CO1 gene, either as sequences or RFLP markers is reliable for strains and populations differentiation study.

Other interesting finding was that genetic differences between wild and captive populations of Mandiangin giant gourami proved that breeding selection might lead to genetic alteration in captive population. This is because breeding selection is directed to obtain individuals with desired character for human. The process will omit alleles for undesired characters from the population. In contrast, alleles for desired characters will accumulate in the population. As the consequences, genetic differences will be observed if we compared wild and captive population. According to Laacy (1987) captive population showed genetic different compared to their relatives in natural population and tend to show low genetic diversity due to strong directional selection.

Based on the used RFLP markers, it can be concluded that genetic homogeneity was occurred within population of wild and captive population of Mandiangin giant gourami. However, significant genetic differences were found between wild and captive population of Mandiangin giant gourami. This indicates genetic alteration has been occurred in captive population.

Table 1. An example of regression analysis for DNA bands size determination

\begin{tabular}{cccc}
\hline Sample Population & $\begin{array}{c}\text { Migration } \\
\text { Distance } \\
(\mathrm{cm})\end{array}$ & $y$-value & $\begin{array}{c}\text { The Size of The CO1 Gene } \\
\text { Amplicon } \\
\text { (base pair) }\end{array}$ \\
\hline Mandiangin Strain from Wild-caught Population (A) & 3.87 & 2.817461 & 657 \\
Mandiangin Strain from Hatchery (B) & 3.02 & 2.816916 & 656 \\
Batanghari Strain from Hatchery (Bt) & 2.31 & 2.8163066 & 655 \\
\hline
\end{tabular}

Table 2. Populations, individual number (n), haplotype number (nhp), polymorphic site, haplotype diversity (h), and locus diversity $(\pi)$

\begin{tabular}{cccccc}
\hline Population & $\mathrm{n}$ & $n h p$ & Polymorphic site & $\mathrm{h}$ & $\pi$ \\
\hline A & 15 & 1 & 0 & 0.000 & 0.000 \\
B & 15 & 1 & 0 & 0.000 & 0.000 \\
C & 10 & 1 & 0 & 0.000 & 0.000 \\
\hline
\end{tabular}




\section{Jurnal Biodjati 4(1):1-10, May 2019 \\ JURNAL BI@DJATI}

http://journal.uinsgd.ac.id/index.php/biodjati

Table 3. Pairwise fixation index ( $\Phi$-st) and variance components values among and within populations

\begin{tabular}{ccccc}
\hline Source of variation & d.f. & Sum of squares & Variance components & $\begin{array}{c}\text { Percentage of vari- } \\
\text { ation }\end{array}$ \\
\hline Among populations & 2 & 13.125 & $0.500 \mathrm{Va}$ & 100.000 \\
Within populations & 37 & 0.000 & $0.000 \mathrm{Vb}$ & 0.000 \\
\hline Total & 39 & 13.125 & 0.000 & \\
\hline Fixation Index $(\Phi-$ st $)$ & 1.000 & & &
\end{tabular}

Remarks: Va and (Ф-st) p-value: 0.000

${ }^{*} 0.05 \geq \mathrm{P} \geq 0.01 ; * * 0.01>\mathrm{P} \geq 0.001 ; * * * \mathrm{P}<0.001 ;$ NS: not significant $(\mathrm{P}>0.5)$

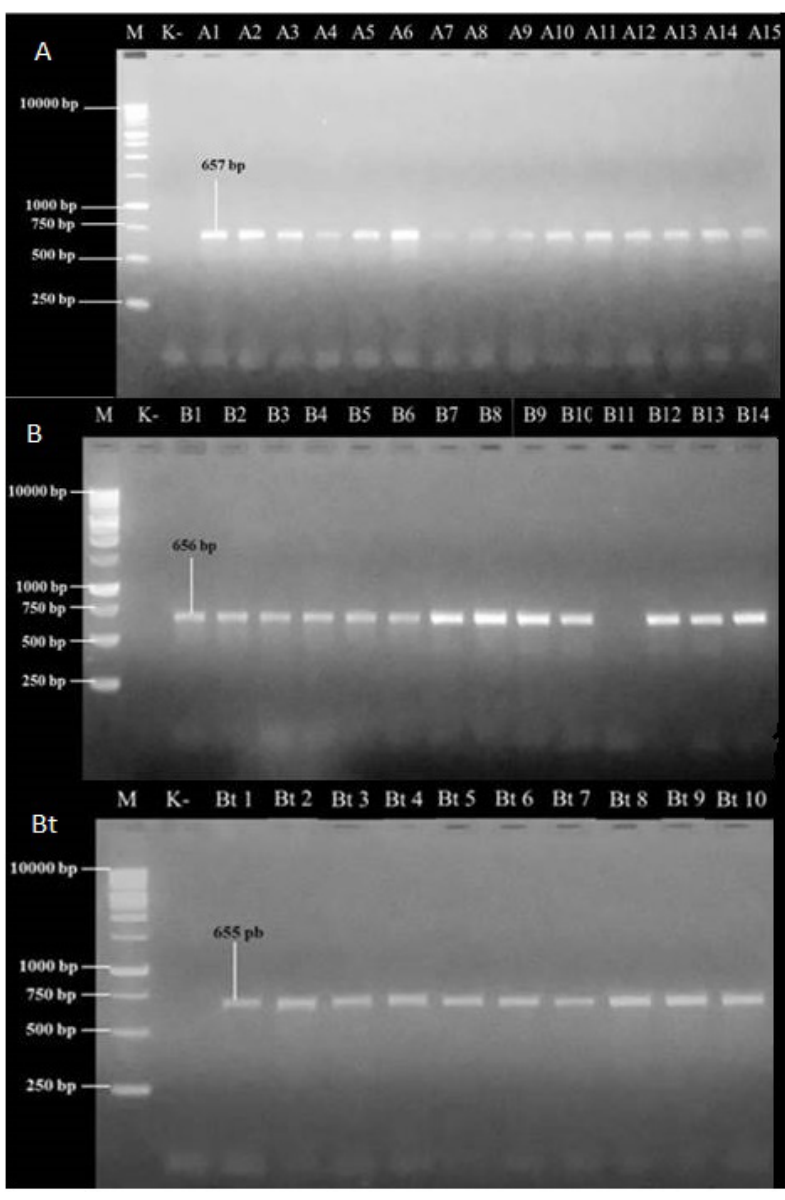

Figure 1. The size of CO1CO1 amplicons from Mandiangin and Batanghari Strains. Remarks: up= wild population of Mandiangin Strain, middle = captive population of Mandiangin Strain, down $=$ captive population of Batanghari Strain, $\mathrm{M}=\mathrm{DNA}$ ladder, $\mathrm{K}=$ = negative control
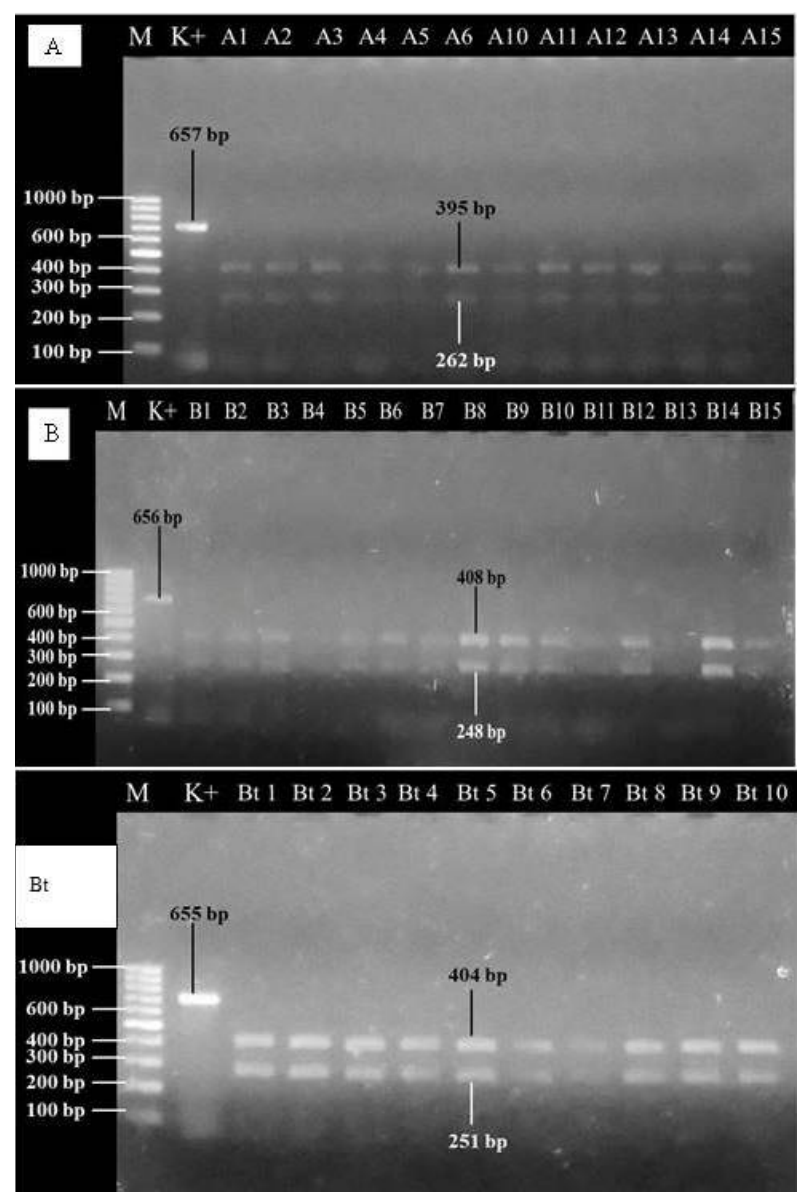

Figure 2. The CO1CO1-HindIII RFLP pattern on Mandiangin and Batanghari populations. Remarks: $A=$ wild population of Mandiamgin Strain, $\mathrm{B}=$ captive population of Mandiangin Strain; $\mathrm{Bt}=$ captive population of Batanghari Strain; $\mathrm{M}=$ DNA ladder; $\mathrm{K}+=$ positive control 


\section{JURNAL BIDDJATI}

http://journal.uinsgd.ac.id/index.php/biodjati

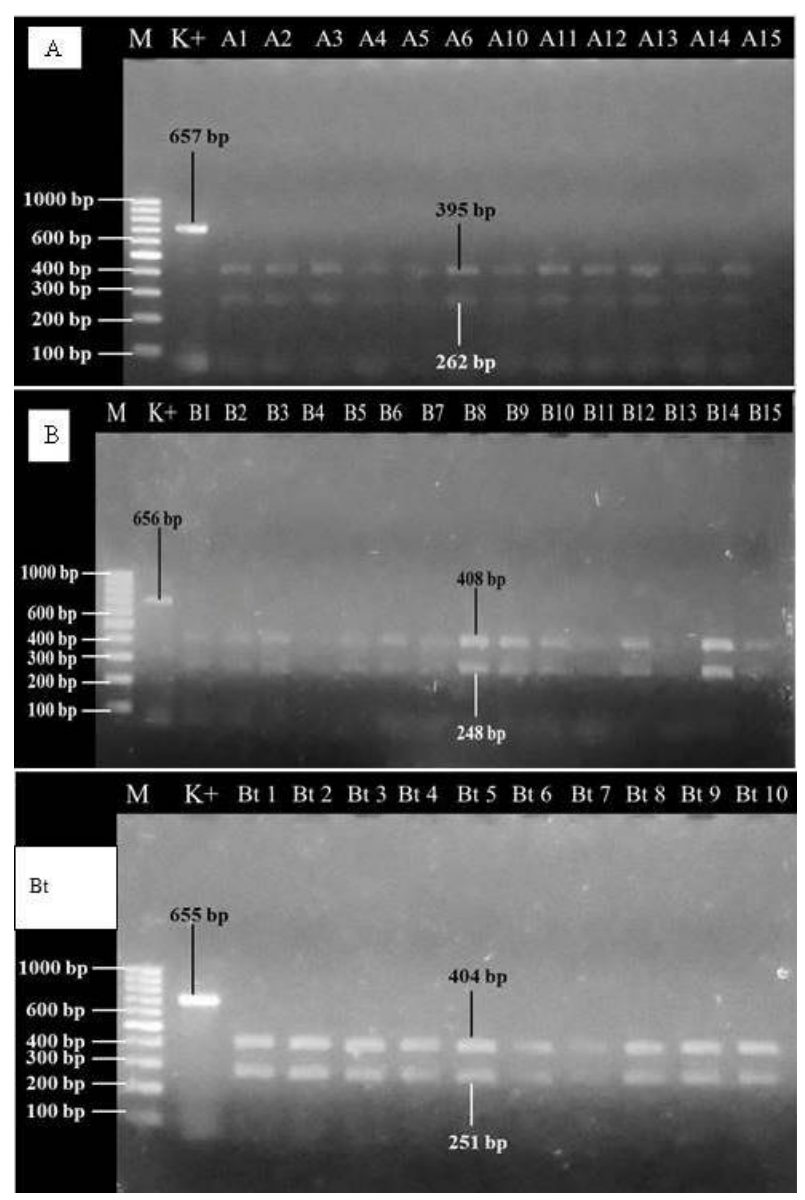

Figure 3. The CO1CO1-TaqI RFLP pattern on Mandiangin and Batanghari populations. Remarks: $\mathrm{A}=$ wild population of Mandiangin Strain, $\mathrm{B}=$ captive population of Mandiangin Strain; $\mathrm{Bt}=$ captive population of Batanghari Strain; $\mathrm{M}=\mathrm{D}$ NA ladder; $\mathrm{K}+=$ positive control

\section{ACKNOWLEDGEMENTS}

We would like to thank to Directorate Research and Public Service (DRPM) Ministry of Research, Technology, and Higher Education the Republic of Indonesia for providing the funding through Hibah Bersaing/ SBK Riset Terapan which was granted to Agus Nuryanto (contract number: 11030/UN23.14/ $\mathrm{PN} / 2017$. High appreciation we deliver to Research and Public Service Institute and Faculty of Biology of Universitas Jenderal Soedirman for the facilitation which makes the study Nuryanto et al. possible to be finished. We are also greatly appreciate and deepest thank is delivered to the Head and staff of BPBAT Mandiangin and BPBAT Sungai Gelam, Jambi who provide valuable help during the field trips. We also give high appreciation to the reviewer(s) who gave helpful comments and suggestion to develop scientific means of this manuscript.

\section{REFERENCES}

Anna, F. (2015). DNA Barcoding of Freshwater Fishes in Matang, Malaysia. Bioin- 


\section{Jurnal Biodjati 4(1):1-10, May 2019 \\ JURNAL BIDDJATI}

http://journal.uinsgd.ac.id/index.php/biodjati

formatics Engineering, Program Uppsa-

la University School of Engineering. Apostolidis, A. P., Loukovitis, D. \& Tsigenopoulos, C. S. (2008). Genetic Characterization of Brown Trout (Salmo trutta) Populations from the Southern Balkans using mtDNA Sequencing and RFLP Analysis. Hydrobiologia, 600(1), 169-176.

Azizah, S. N., Nuryanto, A. \& Pramono, H. (2015). Karakterisasi Molekuler Ikan Gurami Soang (Osphronemus goramy Lac.) Berbeda Ukuran Menggunakan Pcr-Rflp Gen Sitokrom C Oksidase 1. Biosfera, 32(3), 185-193.

Excoffier, L. \& Lischer, H. E. L. (2010). Arlequin suite ver 3.5: A New Series of Programs to Perform Population Genetics Analyses Under Linux and Windows. Molecular Ecology Resources, 10(3), 564-567.

Gholizadeh, A. \& Kohnehrouz, B. B. (2008). Carborundum-Dependent Entrance of EcoRI Restriction Enzyme into Plant Cells and Specific Cleavage of Genomic DNA. Indian Journal of Experimental Biology, 47(8), 684-689.

Ivanova, N. V., Zemlak, T. S., Hanner, R. H. \& Hebert, P.D. N. (2007). Universal Primer Cocktails for Fish DNA Barcoding. Molecular Ecology Notes, 7(4), 544-548.

Kochzius, M. \& Nuryanto, A. (2008). Strong Genetic Population Structure in the Boring Giant Clam, Tridacna crocea, Across the Indo-Malay Archipelago: Implications Related to Evolutionary Processes and Connectivity. Molecular Ecology, 17(17).

Laacy, R. C. (1987). Loss of Genetic Diversity. Conservation Biology, 1(2), 143-158.

Nei, M. \& Jin, L. (1989). Variances of the Average Numbers of Nucleotide Substitutions Within and Between Populations, 6(3), 290-300.
Nuryanto, A. \& Kochzius, M. (2009). Highly Restricted Gene Flow and Deep Evolutionary Lineages in the Giant Clam Tridacna maxima. Coral Reefs, 28(3).

Nuryanto, A. \& Sastranegara, M. H. (2013). Molecular Characterisation of Polymesoda erosa (Solander, 1786) Inhabit Two Different Habitats. Bionatura-Jurnal Ilmu-Ilmu Hayati Dan Fisik, 15, 201-207.

Nuryanto, A. \& Pulungsari, A. E. (2017). Molecular Characteristics of Batanghari, Tambago, Orange, and Mandiangin Giant Gourami Strains. Biosaintifika: Journal of Biology \& Biology Education, 9(3), 592.

Nuryanto, A., Amalia, G., Khairani, D., Pramono, H. \& Bhagawati, D. (2018). Molecular Characterization of Four Giant Gourami Strains from Java and Sumatra. Biodiversitas, 19(2).

Olsen, J. B., Schlei, O., Brown, R., Miller, S. J., Harper, K. \& Wenburg, J. K. (2007). Genetic Species Markers and Population Structure in Alaskan Coregonid Fishes. U.S. Fish and Wildlife Service, Office of Subsistence Management, Fisheries Resource Monitoring Program, Final Reportfor Study 05-702, (June 2007), 1-62.

Santoso, T. J., Hidayat, S. H., Herman, M. \& Aswidinnoor, H. (2008). Identitas dan Keragaman Genetik Begomovirus yang Berasosiasi dengan Penyakit Keriting pada Tomat Berdasarkan Teknik Polymerase Chain Reaction ( PCR ) - Restriction Fragment Length Polymorphism (RFLP). AgroBiogen, 4(1), 9-17.

Sari, A. K., Nuryanto, A. \& Susanto, A. H. (2014). Karakterisasi beberapa strain gurami Osphronemus gouramy Lac. menggunakan marka RAPD. Scripta Biologica, 1(1), 113-116.

Septiawan, J. T., Nuryanto, A., Pramono, H., Kusbiyanto, K. \& Soedibja, P. H. T. 


\section{Jurnal Biodjati 4(1):1-10, May 2019 \\ JURNAL BI@DIATI}

http://journal.uinsgd.ac.id/index.php/biodjati

(2017). Karakterisasi Molekuler Ikan Gurami Soang (Osphronemus gouramy Lac.) yang Mati pada Rentang Waktu Berbeda Menggunakan PCR-RFLP Gen Major Histocompatibility Complex Kelas II B. Biosfera, 33(2), 92.

Setijaningsih, L., Zenaiarifin, O. \& Gustiano, R. (2007). Karakterisasi Tiga Strain Ikan Gurame (Osphronemus gouramy Lac.) [Characterization ofthree strains of giant gouramy (Osphronemus gouramy Lac.) based on truss morphometries method]. Jurnal Lktiologi Indonesia, 7(Tabel 1), 23-30.

Tajung, L. R., Triyanto, Sadi, N. H., Haryani, G. S. \& Said, D. S. (2011). Uji Ketahanan Beberapa STrain Ikan Gurami Terhadap Penyakit Aeromonas Livia R. Limnotek, 18(1), 58-71.

Walsh, P. S., Metzger, D. A. \& Higuchi, R. (2013). Biotechniques 30th Anniversary Gem Chelex 100 as a Medium for Simple Extraction of DNA for PCRBased Typing from Forensic Material. BioTechniques, 54(3), 506-513.

Ward, R. D., Zemlak, T. S., Innes, B. H., Last, P. R. \& Hebert, P. D. N. (2005). DNA Barcoding Australia's Fish Species. Phil. Trans. R. Soc. B, 360, 1847-1857.
Ward, R. D., Costa, F. O., Holmes, B. H. \& Steinke, D. (2008a). DNA Barcoding of Shared Fish Species from the North Atlantic and Australasia: Minimal Divergence for Most Taxa, but Zeus faber and Lepidopus caudatus each Probably Constitute Two Species. Aquatic Biology, 3(1), 71-78.

Ward, R. D., Holmes, B. H., White, W. T. \& Last, P. R. (2008b). DNA Barcoding Australasian Chondrichthyans: Results and Possible Uses in Conservation. Marine and Freshwater Research, 59(1), 57-71.

Ward, R. D., Hanner, R. \& Hebert, P. D. N. (2009). The Campaign to DNA Barcode All Fishes, FISH-BOL. Journal of Fish Biology, 74(2), 329-356.

Yoon, J. \& Park, H. (2002). Genetic Similarity and Variation in the Cultured and Wild Crucian Carp (Carassius carassius) Estimated with Random Amplified Polymorphic DNA. Asian Australasian Journal of Animal Science, 15(4), 470-476.

Zhang, J. \& Hanner, R. (2012). Molecular approach to the identification of fish in the South China Sea. PLoS ONE, 7(2), 1-9 